\title{
Identification and characterisation of oil sludge degrading bacteria isolated from compost
}

\author{
Onyedikachi Ubani ${ }^{1 *}$, Harrison Ifeanyichukwu Atagana ${ }^{2}$, Mapitsi Silvester Thantsha ${ }^{3}$, Adeleke Rasheed ${ }^{4}$
}

\author{
${ }^{1}$ University of South Africa, South Africa \\ Department of Environmental Sciences \\ ${ }^{2}$ University of South Africa, South Africa \\ Institute for Science and Technology Education \\ ${ }^{3}$ University of Pretoria, South Africa \\ Department of Microbiology and Plant Pathology \\ ${ }^{4}$ Agricultural Research Council, South Africa \\ Institute for Soil, Climate and Water
}

*Corresponding author's e-mail: onyedika.ubani@gmail.com

Keywords: Bioaugmentation, biodegradation, bioremediation, composting, oil sludge, PAHs, animal manures.

\begin{abstract}
Compounds present in oil sludge such as polycyclic aromatic hydrocarbons (PAHs) are known to be cytotoxic, mutagenic and potentially carcinogenic. Microorganisms including bacteria and fungi have been reported to degrade oil sludge components to innocuous compounds such as carbon dioxide, water and salts. In the present study, we isolated different bacteria with PAH-degrading capabilities from compost prepared from oil sludge and animal manures. These bacteria were isolated on a mineral base medium and mineral salt agar plates. A total of 31 morphologically distinct isolates were carefully selected from 5 different compost treatments for identification using polymerase chain reaction (PCR) of the 16S rRNA gene with specific primers (universal forward 16S-P1 PCR and reverse 16S-P2 PCR). The amplicons were sequenced and sequences were compared with the known nucleotides from the GenBank. The phylogenetic analyses of the isolates showed that they belong to 3 different clades; Firmicutes, Proteobacteria and Actinobacteria. These bacteria identified were closely related to the genera Bacillus, Arthrobacter, Staphylococcus, Brevibacterium, Variovorax, Paenibacillus, Ralstonia and Geobacillus. The results showed that Bacillus species were predominant in all composts. Based on the results of the degradation of the PAHs in the composts and results of previous studies on bacterial degradation of hydrocarbons in oil, the characteristics of these bacterial isolates suggests that they may be responsible for the breakdown of PAHs of different molecular weights in the composts. Thus, they may be potentially useful for bioremediation of oil sludge during compost bioremediation.
\end{abstract}

\section{Introduction}

Waste sludge encountered during crude oil refining and cleaning of oil storage vessels contains large amounts of hydrocarbons including aromatic hydrocarbons in the range of 1-40 carbon atoms (Diallo et al. 2000). Oil sludge has been classified by the United States Environmental Protection Agency (US EPA) as a hazardous organic complex (Liu etal.2010). Oil sludge is usually contained in sludge pits or dams but enters the environment as a result of human activities, which include deliberate dumping, improper treatments and management, storage, transportation and landfill disposal. This is an environmental concern, as many of the oil sludge components are known to be cytotoxic, mutagenic and potentially carcinogenic (Bojes and Pope, 2007, Bayoumi, 2009, Barnabas et al. 2013, Singh and Chandra, 2014). Therefore, treatment of this contaminant is essential to reduce the hazardous effect associated with oil sludge contamination in the environment.

Treatment of oil sludge can be achieved through physical, chemical and biological methods (Srinivasarao et al. 2011,
Udotong et al. 2011). Of these, the biological method stands out as the most environmentally friendly option. A common biological approach is the use of microorganisms for the degradation oil sludge in the environment (Paulauskiene et al. 2009). Microbial biodegradation is an effective and inexpensive approach for the degradation of petroleum hydrocarbons (Philips et al. 2000). This is possible as long as a large population of degrading microorganisms is present and the conditions are adequate for microbial growth and activities (Philips et al. 2000).

The initial step in the catabolism of oil sludge by bacteria and fungi involves the oxidation of the substrate by oxygenases (Marin Millan, 2004). The use of microorganisms in degrading oil sludge is nature-compatible, reliable, cheaper and easy to adopt compared to physical and chemical methods (Machin-Ramirez et al. 2008). The negative effect of this technique is minimal to the environment and may eliminate the waste permanently, without long term liability, as such it has greater public acceptance.

Composting is a controlled biological process and consists of a mixture of substrates carried out by large successive microbial population combining both mesophilic 
and thermophilic activities. Microbial activities in compost generate high temperature, which increases solubility of contaminants and induces microbial co-metabolic activity (Sheetal 2012). In compost, there is abundance of nutrients and organic matter that have effect on microbial degradation of oil sludge constituents (Sheetal 2012). As the compost matures, the pollutants are degraded, digested, metabolised and transformed into humus as well as inert products such as carbon dioxide, water and salts.

In this study, the initial concentrations of the PAHs ( 2 to 6 rings) detected were between $1.44 \mathrm{mg} / \mathrm{kg}$ to $205.81 \mathrm{mg} / \mathrm{kg}$ before the co-composting process of oil sludge. The results obtained showed reduction in selected PAHs (66\% to $80 \%)$ in all co-composting piles over a period of ten months, as shown in Table 3. This result is in agreement with the report from comparison of bioaugmentation and composting for remediation of oil sludge (Ouyang et al. 2005). The results obtained from the compost piles showed that composting can be used to degrade PAHs present in oil sludge, suggesting the existence of active bacterial community in the compost (Katsivela et al. 2003). This study was to determine whether microbial growth and activities were enhanced as well as bacteria community involved in the degradation of oil sludge (PAHs) during the composting period.

Culture dependent and non-culture dependent methods have been used to determine the composition of the metabolically active microorganisms that played an important role in the degradation of pollutants (Saman 2010). Culture dependent methods (CDM) often involve proper isolation and in vitro cultivation of microorganisms based on their required growth factors (Saman 2010), while non-culture dependent method is used for identification of uncultivable microorganism. These methods complement each other to enable the identification of more than $90 \%$ microorganisms. Perhaps, the most widely used non-culture dependent method is the molecular method. This usually involves direct DNA extraction from samples, PCR amplification and nucleotide sequence for identification of microbial diversity based on the analysis of the 16SrRNA gene sequences (Mokno-Tlili et al. 2009, Inceoglu et al. 2010). It is a reliable method that can be used to detect diversity, quantity and sometimes viability of microbial contents of a sample (Inceoglu et al. 2010, Saman, 2010). However, it seems that combination of both methods is always essential in isolation and characterisation of bacterial isolates.

The aim of this study was to isolate, identify and characterise bacterial consortium present in a compost system with potentials to degrade PAHs present in oil sludge.

\section{Materials and methods}

\section{Soil}

Garden soil was air-dried and analysed to determine the soil type, organic carbon content, total nitrogen content, total phosphorus content $(\mathrm{C} ; \mathrm{N}$ and $\mathrm{P})$, soil $\mathrm{pH}$ and water holding capacity (WHC), using concentrated acid digestion method (CADM) with Induction Coupled Plasma (ICP-OES Optima 4300 DV, Perkin Elmer, Waltham, MA, USA).

\section{Oil sludge}

Oil sludge from a refinery was soxhlet extracted with dichloromethane as the solvent and characterized by gas chromatography/mass spectrometry (GC/MS) method (US EPA 8270 2007, Bobak 2010).

\section{Animal manures}

Cow, pig, horse, and poultry manures collected from University of Pretoria, Onderstepoort, Pretoria, South Africa were characterized for organic carbon content, total nitrogen content, total phosphorus content.

\section{Bulking agent}

The bulking agent used to enhance aeration was wood-chips of $8-10 \mathrm{~cm} \times 0.3-0.5 \mathrm{~cm}$.

\section{Chemicals}

Carbon tetrachloride $\left(\mathrm{CCl}_{4}, 99.55 \%\right)$, molar mass 153.8236 $\mathrm{g} / \mathrm{mol}$, density $1.594 \mathrm{~g} / \mathrm{ml}$ ) was purchased from Merck South Africa and used to dissolve the oil sludge before mixing with soil.

\section{Preparation of compost mixture}

Eight hundred grams of crude oil sludge was dissolved in $400 \mathrm{ml} \mathrm{of} \mathrm{CCl}_{4}$. Then the mixture was added to $4 \mathrm{~kg}$ of soil and air dried at room temperature to evaporate excess $\mathrm{CCl}_{4}$ after which $100 \mathrm{~g}$ was analysed for selected PAHs as shown in Table 1. Wood chips were mixed with the amended soil in a ratio of 1:2 (w:v) soil:wood chips. The mixture was divided into five parts of about $2.34 \mathrm{~kg}$ each and four parts were separately mixed with about $1.17 \mathrm{~kg}$ of either pig, cow, horse or poultry manures in a ratio of 2:1 (w:w). The fifth portion was used as the control with no manure added. All treatments including the control were incubated in PVC troughs at room temperature for a period of ten months. All treatments were replicated three times. Temperature, moisture content, $\mathrm{pH}$ and respiration of compost organisms were measured monthly. Organisms present in the compost were isolated and characterised by molecular methods.

\section{Isolation of degrading PAHs bacteria Mineral salt medium (MSM)}

The mineral salts medium was used for enrichment culture and contained in $\mathrm{mg} \mathrm{L}^{-1} ; 500 \mathrm{mg} \mathrm{KH} \mathrm{PO}_{4}, 500 \mathrm{mg} \mathrm{MgSO}_{4}$. $7 \mathrm{H}_{2} \mathrm{O}, 500 \mathrm{mg} \mathrm{NaH} \mathrm{PO}_{4} \cdot \mathrm{H}_{2} \mathrm{O}, 500 \mathrm{mg} \mathrm{NH} \mathrm{Cl}_{4} \mathrm{Cl}, 4000 \mathrm{mg} \mathrm{NaCl}$, $500 \mathrm{mg} \mathrm{NaHCO}$ and $500 \mathrm{mg} \mathrm{Na} \mathrm{CO}_{3}$ and $1 \mathrm{ml}$ trace elements solutions contained in $\mathrm{mg} \mathrm{L}^{-1}$ distilled water $1500 \mathrm{mg} \mathrm{FeCl}$. $\mathrm{H}_{2} \mathrm{O}, 9000 \mathrm{mg} \mathrm{NaCl}, 197 \mathrm{mg} \mathrm{MnCl}_{2} .4 \mathrm{H}_{2} \mathrm{O}, 900 \mathrm{mg} \mathrm{CaCl}$, $238 \mathrm{mg} \mathrm{CoCl}$. $\mathrm{H}_{2} \mathrm{O}, 17 \mathrm{mg} \mathrm{CuCl}$. $\mathrm{H}_{2} \mathrm{O}, 287 \mathrm{mg} \mathrm{ZnSO}, 50 \mathrm{mg}$ $\mathrm{AlCl}_{3}, 62 \mathrm{mg} \mathrm{H}_{3} \mathrm{BO}_{3}, 24 \mathrm{mg} \mathrm{NiCl} \cdot 6 \mathrm{H}_{2} \mathrm{O}, 10 \mathrm{ml} 10.18 \mathrm{M} \mathrm{HCl}$ (32\%) which were dispensed into $250 \mathrm{ml}$ Erlenmeyer flasks. All solutions were dispensed under aseptic conditions.

\section{Enrichment culture}

Five samples of about $100 \mathrm{~g}$ each were collected from different parts of each compost experiment at the end of ten month incubation and pooled to make a composite sample. In each of $250 \mathrm{ml}$ Erlenmeyer flasks containing $100 \mathrm{ml}$ sterile MSM spiked with $10 \mathrm{ml}$ oil sludge, $15 \mathrm{~g}$ of compost from the pooled sample was added. Control experiments similar to the one described above but without oil sludge were set up. The flasks were stoppered with aluminium foil cotton wool bungs and incubated in the dark at $28^{\circ} \mathrm{C}$ on a rotary shaker at $150 \mathrm{rpm}$ for 21 days. All experiments were set up in triplicates. One 
millilitre was aseptically transferred from each flask into another set of $250 \mathrm{ml}$ flasks containing $100 \mathrm{ml}$ sterile MSM spiked with $10 \mathrm{ml}$ of oil sludge and incubated for another 21 days at $28^{\circ} \mathrm{C}$ in a rotary shaker in the dark. At the end of each incubation period, samples were withdrawn from each flask for determination of concentrations of selected PAHs by gas chromatography/mass spectrometry (GC/MS). The final culture was used for the isolation and identification of the oil sludge degraders.

\section{Mineral salts agar (MSA)}

In $900 \mathrm{ml}$ of mineral salts medium, $20 \mathrm{~g}$ of bacteriological agar was added and the mixture was sterilised in an autoclaved at $121^{\circ} \mathrm{C}$ for $15 \mathrm{~min}$. The medium was allowed to cool to about $50^{\circ} \mathrm{C}$ before adding $1 \mathrm{ml}$ of trace element solution, which was previously filtered through $0.2 \mu \mathrm{m}$ membranes filter (Millipore) before dispensing in Petri dishes under aseptic conditions. Each plate was overlaid with $50 \mu \mathrm{L}$ of filter sterilised oil sludge.

\section{Isolation of oil degrading bacteria from enrichment cultures}

Oil degrading bacteria were isolated from the enrichment cultures by serial dilution $\left(10^{-8}\right)$. A $0.1 \mathrm{ml}$ aliquot of each diluent from the $10^{-6}$ to $10^{-8}$ dilutions was inoculated on the mineral salts agar (MSA) plates. The plates were incubated for $21-28$ days at $28^{\circ} \mathrm{C}$ and checked daily for bacteria growth. Distinct colonies from the MSA plates were transferred onto nutrient agar plates and incubated for three days at $28^{\circ} \mathrm{C}$. Pure cultures were made from distinct colonies from nutrient agar plates by serial dilution $\left(10^{-3}\right)$, plated on nutrient agar plate and incubated for three days at $28^{\circ} \mathrm{C}$. Distinct colonies were further purified by streaking onto nutrient agar plates. Identification of the isolates was done by molecular techniques.

\section{Nutrient broth}

Nutrient broth powder (16 g) was prepared in $1 \mathrm{~L}$ bottle containing $1000 \mathrm{ml}$ distilled water which was sterilised at $121^{\circ} \mathrm{C}$ for $15 \mathrm{~min}$ and allowed to cool at room temperature before $10 \mathrm{ml}$ each was dispensed into autoclaved test tubes with cap. Then single colonies obtained on the nutrient agar plates were transferred into the $10 \mathrm{ml}$ nutrient broth mixture and incubated for three days at $28^{\circ} \mathrm{C}$.

\section{Molecular characterisation of isolates}

\section{Genomic DNA extraction of the bacteria isolates}

Genomic DNA extraction was conducted using cetyltrimethyl ammonium bromide method (CTAB) in sterile eppendorf tubes. About $10 \mathrm{ml}$ of the pure cultures in nutrient broth was vortexed and $1.5 \mathrm{ml}$ of it was transferred into $2 \mathrm{ml}$ eppendorf tubes and centrifuged with a microcentrifuge (Eppendorf Minispin plus, $12 \times 1.5 / 2.0 \mathrm{ml}$ ) at $14000 \mathrm{rpm}$ for $5 \mathrm{~min}$. The supernatants were discarded to recover the pellets, which were then resuspended in a solution containing $567 \mu \mathrm{l}$ of tris ethylene diamine tetraactic acid buffer (tris EDTA or TE buffer), $30 \mu \mathrm{l}$ of $10 \%$ sodium dodecyl sulphate (SDS) and $3 \mu \mathrm{l}$ of proteinase $\mathrm{K}(20 \mathrm{mg} / \mathrm{ml})$ and incubated in Accu block digital dry bath incubator at $65^{\circ} \mathrm{C}$ for $1 \mathrm{~h}$. Then $180 \mu \mathrm{l}$ of $5 \mathrm{M}$ $\mathrm{NaCl}$ and $80 \mu \mathrm{l}$ of $10 \% \mathrm{CTAB}$ solutions were added to the mixture and incubated for $10 \mathrm{~min}$ at $65^{\circ} \mathrm{C}$. Equal volumes $(400 \mu \mathrm{l})$ of phenol and chloroform were added to each tube and centrifuged at $14000 \mathrm{rpm}$ for $15 \mathrm{~min}$ and then $300 \mu \mathrm{l}$ of the supernatant was transferred into new sterile eppendorf tubes and the DNA was precipitated by adding $0.6 \mathrm{ml}$ cold isopropanol to each tube. The precipitate was collected by spinning the tube in a centrifuge at $14000 \mathrm{rpm}$ for $15 \mathrm{~min}$ and the supernatant was discarded. Then $200 \mu 1$ of $70 \%$ ethanol was added to the tube to wash DNA pellets by spinning at $14000 \mathrm{rpm}$ for $10 \mathrm{~min}$. The supernatant was carefully removed to air-dry the DNA pellets and $100 \mu 1$ of TE buffer was added to the dried DNA pellets and incubated at $37^{\circ} \mathrm{C}$ for 60 mins to dissolve the DNA pellets. Then $1 \mu 1$ of RNAase was added to the tube and incubated at $37^{\circ} \mathrm{C}$ for 60 mins. The DNA was separated electrophoretically with $1 \%$ agarose gel stained with $0.1 \mu \mathrm{g} / \mathrm{ml}$ ethidium bromide running at $80 \mathrm{~V}$ for 60 mins, using tris acetate EDTA (TAE) Electrophoresis buffer. The DNA was visualised by UV fluorescence to determine the success of the extraction process.

\section{Polymerase chain reaction (PCR) and sequencing}

The master mix aliquot for the PCR was dispensed into individual PCR tubes and the different DNA samples were added to each tube. The negative control was used to check for contamination in the master mix. The PCR reagents in each tube amounted to $50 \mu \mathrm{l}$ containing: buffer $(5 \mu \mathrm{l}), \mathrm{MgCl}_{2}(1.5 \mu \mathrm{l})$, universal primer1 ( $2 \mu$ l forward), primer2 $(2 \mu 1$ reverse), dNTP mix $(1 \mu \mathrm{l})$, Dream Taq DNA Polymerase $(0.25 \mu \mathrm{l})$, sterile sabax water $(35.25 \mu \mathrm{l})$ and DNA samples $(3 \mu \mathrm{l})$. The PCR reactions were performed using MJ Mini thermal cycler (Bio-Rad, Hercules, CA, USA). The PCR products were separated electrophoretically with $1 \%$ agarose gel stained with $0.1 \mu \mathrm{g} / \mathrm{ml}$ ethidium bromide running at $80 \mathrm{~V}$ for 60 mins, using TAE Electrophoresis buffer. The PCR products were visualised by UV fluorescence to determine the size of the amplified bands. The PCR products ( $20 \mu \mathrm{l}$ each) were later cleaned up using $160 \mu \mathrm{l}$ of $13 \%$ polyethylene glycol (PEG) 8000, $20 \mu \mathrm{l}$ of $5 \mathrm{M} \mathrm{NaCl}$ solution and $200 \mu \mathrm{l}$ of $70 \%$ ethanol. Cleaned PCR products were sequenced at the Forestry and Agricultural Biotechnology Institute (FABI) sequencing facility, University of Pretoria, South Africa. The sequences of the 16S rRNA region obtained were edited using BioEdit software and the edited sequences were copied in a FASTA format. Blasting was done on National Centre for Biotechnology Information (NCBI) website. This was to check and compare the sequences with those on the database. From the list of many identical sequences, four were selected for each bacterium from the GenBank for phylogenetic analyses.

\section{Phylogenetic analyses}

The bacterial sequences from the five treatments, control, cow, horse, pig and poultry were aligned using online version of MAFFT software. The phylogenetic analyses were done using Mega 4 software and evolutionary distance of the isolates was computed using neighbour-joining (NJ) methods. The bootstrap consensus tree was inferred from 1000 replicates and all positions containing gaps as well as missing nucleotide data were eliminated from the data-set. Vibrio cholerae was used as the out-group.

\section{Results and discussion}

The soil used in this study was a sandy-loam soil. The initial $\mathrm{pH}$ of the soil was 5.56 and carbon, nitrogen and phosphate content 
was 102, 20 and 4.4 $\mathrm{mg} \mathrm{L}^{-1}$ respectively (Table 4). The water holding capacity of the soil was $32.62 \%$. Selected polycyclic aromatic hydrocarbons (PAHs) present in the oil sludge are shown in Table 2. The characteristics of the manures (pig, horse, cow and poultry), including carbon, nitrogen phosphorus content are shown in Table 2. Growth appeared in all the plates after incubation for 21 days at $28^{\circ} \mathrm{C}$. The isolates include both gram-positive and gram-negative bacteria. The gram-staining results of the isolates showed mostly gram-positive bacteria and they were dominant in all the compost treatments. The isolates were mostly short and long rods, and a few cocci. A total of 31 morphologically distinct isolates were selected from the different compost treatments for molecular characterisation. They included five isolates from the control experiments, two from horse manure compost, ten from cow manure compost, five isolates from poultry manure compost and nine isolates from pig manure compost. The oligonucleotide primers used amplified 1500 base pairs of 16S rRNA gene fragments using $3 \mu \mathrm{l}$ DNA sample. The homology sequence and phylogenetic analyses of the 16S rRNA of the isolates showed that they belong to 3 different clades namely Firmicutes, Proteobacteria and Actinobacteria (Figs 1-5). The distinct grouping of these organisms strongly supported the phylogenetic relationship between the organisms with high bootstrap (Figs 1-5). This result showed that these isolates represent distinct groups that are closely related to form a coherent group in a synergistic relationship to degrade their target pollutants (Barnabas et al. 2013). From the results, it was shown that most of the isolates belong to the Firmicutes clade, which included CT2, CT3, CT5, Co3, Co4, Co7, Co8, Co9, Co10, Co12, H1, H4, Pi1, Pi2, Pi4, Pi5, Pi7, Pi9, Pi12, Po1, Po2, Po3, Po4 and Po5. The isolates for the Proteobacteria clades belongs to the subdivision BetaProteobacteria, which included CT4 and Co6, while the Actinobacteria clade consisted of isolates CT1, Co2, Pi10, Pi13. Vibrio cholerae was used as the out group. The molecular and phylogenetic analyses of the isolates showed that they are closely related to 8 genera. These are Staphylococcus (CT2, $\mathrm{Co} 7$ and C08), Brevibacterium (CT1), Variovorax (Co6), Arthrobacter (Co2, Pi10 and Pi13), Bacillus (Co3, Co4, Co9, Co10, Co12, H1, H4, Pi2, Pi4, Pi5, Pi7, Pi9, Pi12, Po2, Po3, Po4 and Po5), Paenibacillus (CT3 and Po1), Ralstonia (CT4) and Geobacillus (CT5) These isolates have been allocated the accession numbers (JQ808080 - JQ808120) and their closely related genera from the GenBank are shown in Figs 1-5. The results obtained in Table 3 were the pooled samples from the enrichment cultures, not of individual enrichment cultures. The subculture indicated in Table 3, is the subsequent culture made with one aliquot of the original enrichment culture. The results in Table 3 are also the means of three replicates and because there are very many PAHs in each culture, selected ones are those with significant initial concentration. The results obtained from enrichment culture samples were analysed

Table 1. Concentration of the selected PAHs present in oil sludge $(\mathrm{mg} / \mathrm{kg})$. Values are mean of three actual values \pm standard error

\begin{tabular}{|c|c|c|c|c|c|c|c|c|c|c|c|c|c|c|c|c|}
\hline 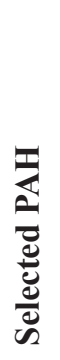 & 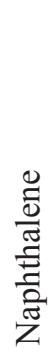 & 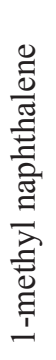 & 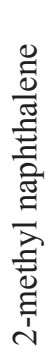 & 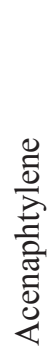 & 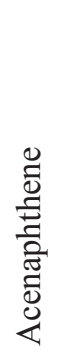 & 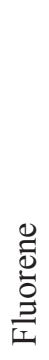 & 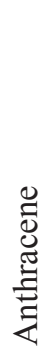 & 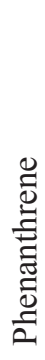 & 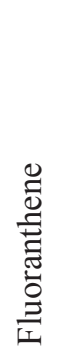 & 营 & 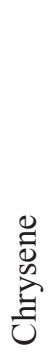 & 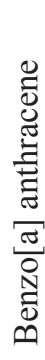 & 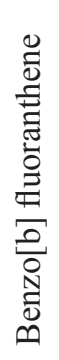 & 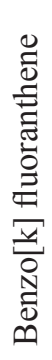 & 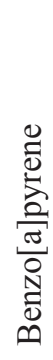 & 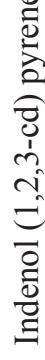 \\
\hline 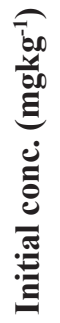 & 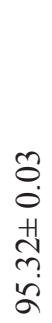 & $\begin{array}{l} \pm \\
\overrightarrow{0} \\
\ddot{H} \\
\dot{\infty} \\
\dot{0} \\
0\end{array}$ & 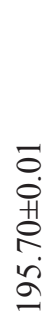 & $\begin{array}{l}0 \\
\text { Hे } \\
\text { on } \\
\text { in }\end{array}$ & 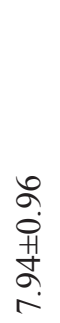 & 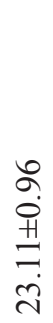 & 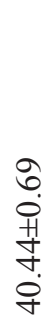 & $\begin{array}{l}\stackrel{g}{+} \\
\text { 贲 } \\
\text { 导. }\end{array}$ & $\begin{array}{l}\text { O } \\
\stackrel{+}{0} \\
\text { H } \\
\text { 导. }\end{array}$ & $\begin{array}{l}m \\
\text { ñ. } \\
\text { N } \\
\infty \\
0 \\
0\end{array}$ & $\begin{array}{l}\stackrel{0}{0} \\
\stackrel{+}{+} \\
\stackrel{f}{*} \\
\dot{f}\end{array}$ & $\begin{array}{l}\text { ñ } \\
\text { on } \\
\text { 莳 } \\
\text { - }\end{array}$ & $\begin{array}{l}\vec{i} \\
\vec{H} \\
\stackrel{0}{0} \\
\vec{i}\end{array}$ & $\begin{array}{l}\stackrel{0}{\circ} \\
\stackrel{+1}{I} \\
\stackrel{i}{N}\end{array}$ & 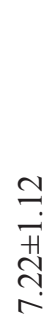 & $\begin{array}{l}\stackrel{\infty}{\infty} \\
\underset{\sim}{+} \\
\stackrel{\infty}{\infty} \\
i\end{array}$ \\
\hline
\end{tabular}

Table 2. Characteristics of animal manures for Carbon, Nitrogen and Phosphorus. Values are mean of three actual values \pm standard error

\begin{tabular}{|c|c|c|c|}
\hline Animal manures & Total organic C [\%] & Total $\left.\mathrm{N}^{\mathrm{mgL}}{ }^{-1}\right]$ & Total $\mathrm{P}\left[\mathrm{mgL}^{-1}\right]$ \\
\hline Poultry & $49.2 \pm 14.2$ & $277 \pm 63$ & $254 \pm 14$ \\
\hline Cow & $54.9 \pm 5.9$ & $109 \pm 8$ & $46 \pm 8$ \\
\hline Horse & $52.7 \pm 2.7$ & $81 \pm 3$ & $50 \pm 2$ \\
\hline Pig & $50.6 \pm 5.9$ & $904 \pm 84$ & $252 \pm 29$ \\
\hline
\end{tabular}


Table 4. Characteristics of garden soil used for the experiment

\begin{tabular}{|l|c|}
\hline Soil parameter & Characteristics [Conc] \\
\hline Sand [\% wt] & 61.3 \\
\hline Silt [\% wt] & 21.3 \\
\hline Clay [\% wt] & 9.3 \\
\hline Texture & sandy loam \\
\hline pH (H2O) & 5.56 \\
\hline Total organic carbon in \%[mg/l] & 1.02 \\
\hline Total organic N [mg/l] & 20 \\
\hline Total P [mg/l] & 4.4 \\
\hline Cr [mg kg-1] & 121.7 \\
\hline Pb [mg kg-1] & 31.91 \\
\hline Ni [mg kg-1] & 10.13 \\
\hline Cu [mg kg-1] & 38.08 \\
\hline Zn [mg kg-1] & 9.65 \\
\hline Mn [mg kg-1] & 92.38 \\
\hline Fe [mg kg-1] & 67.04 \\
\hline Co [mg kg-1] & 2.45 \\
\hline Mg [mg kg-1] & 22.37 \\
\hline Dry matter content [\% DM] & 90.48 \\
\hline Moisture content [\% MC] & 9.52 \\
\hline
\end{tabular}

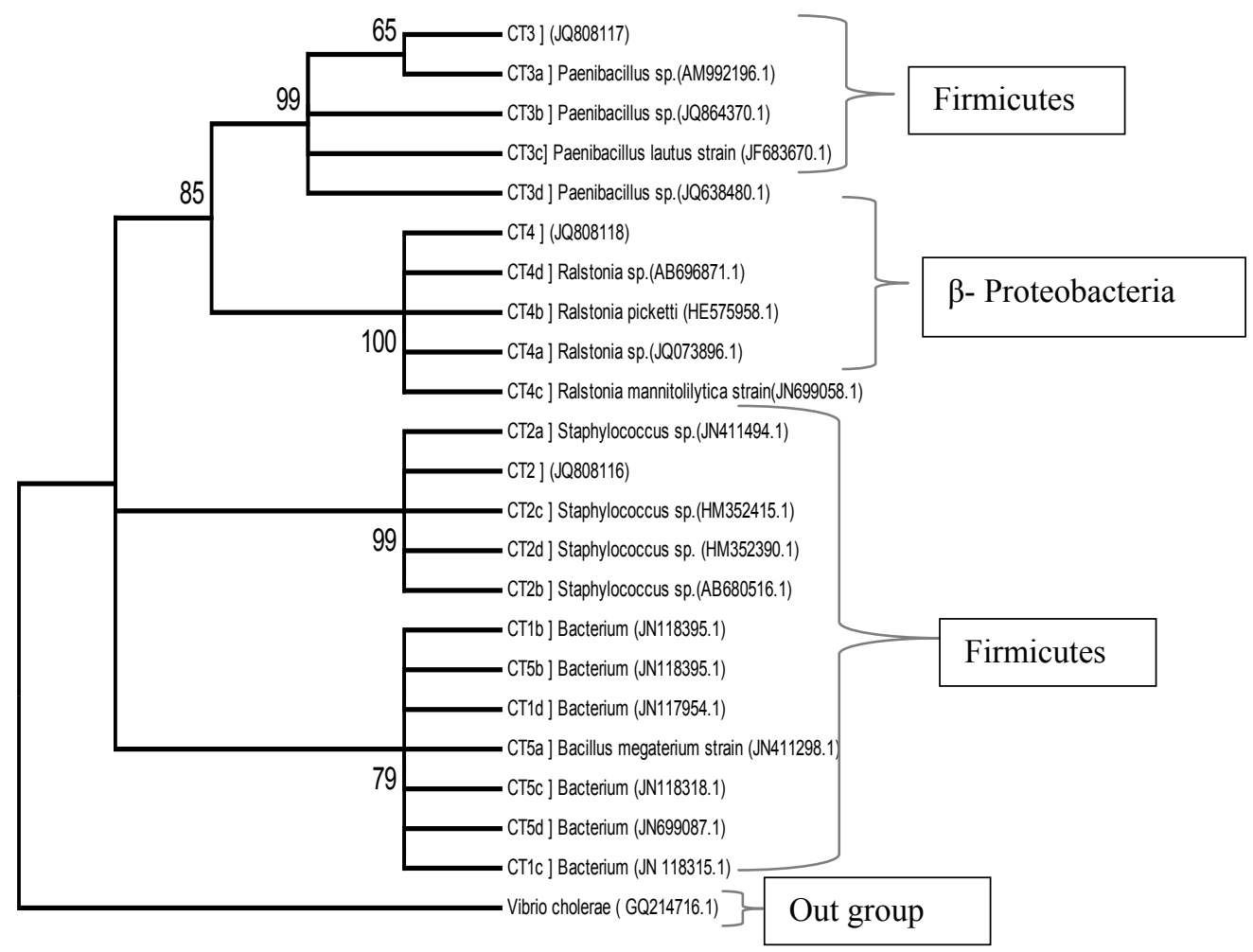

Fig. 1. Neighbour joining tree showing partial sequences of $16 \mathrm{~S}$ rDNA of bacteria isolates from group 1 (control) and their related species obtained from the GenBank as computed by boostrap NJ method 


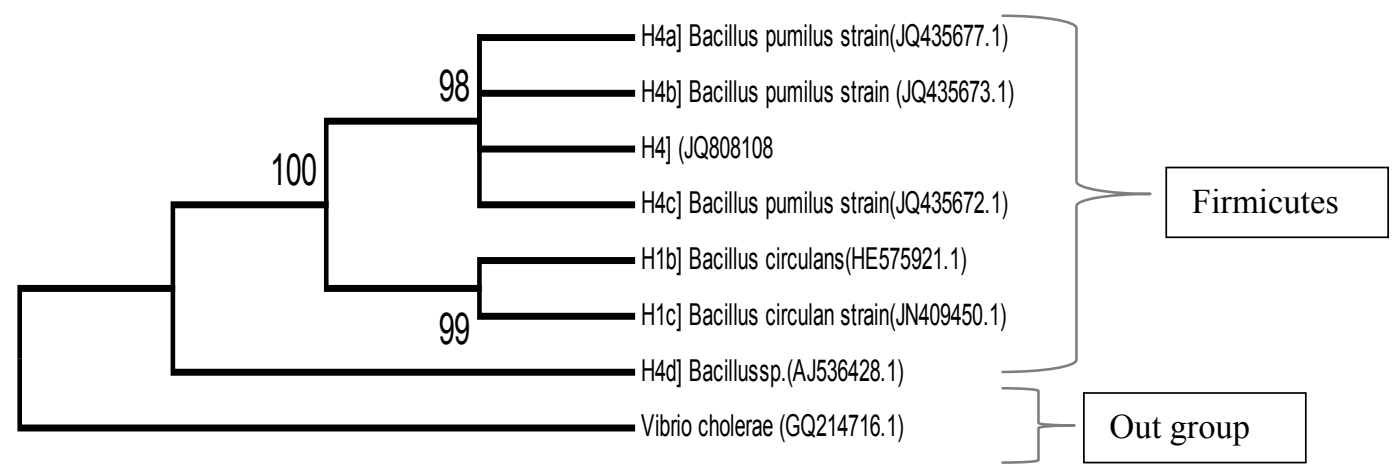

Fig. 2. Neighbour joining tree showing partial sequences of $16 \mathrm{~S}$ rDNA of bacteria isolates from group 3 (horse) and their related species obtained from the GenBank as computed by boostrap NJ method

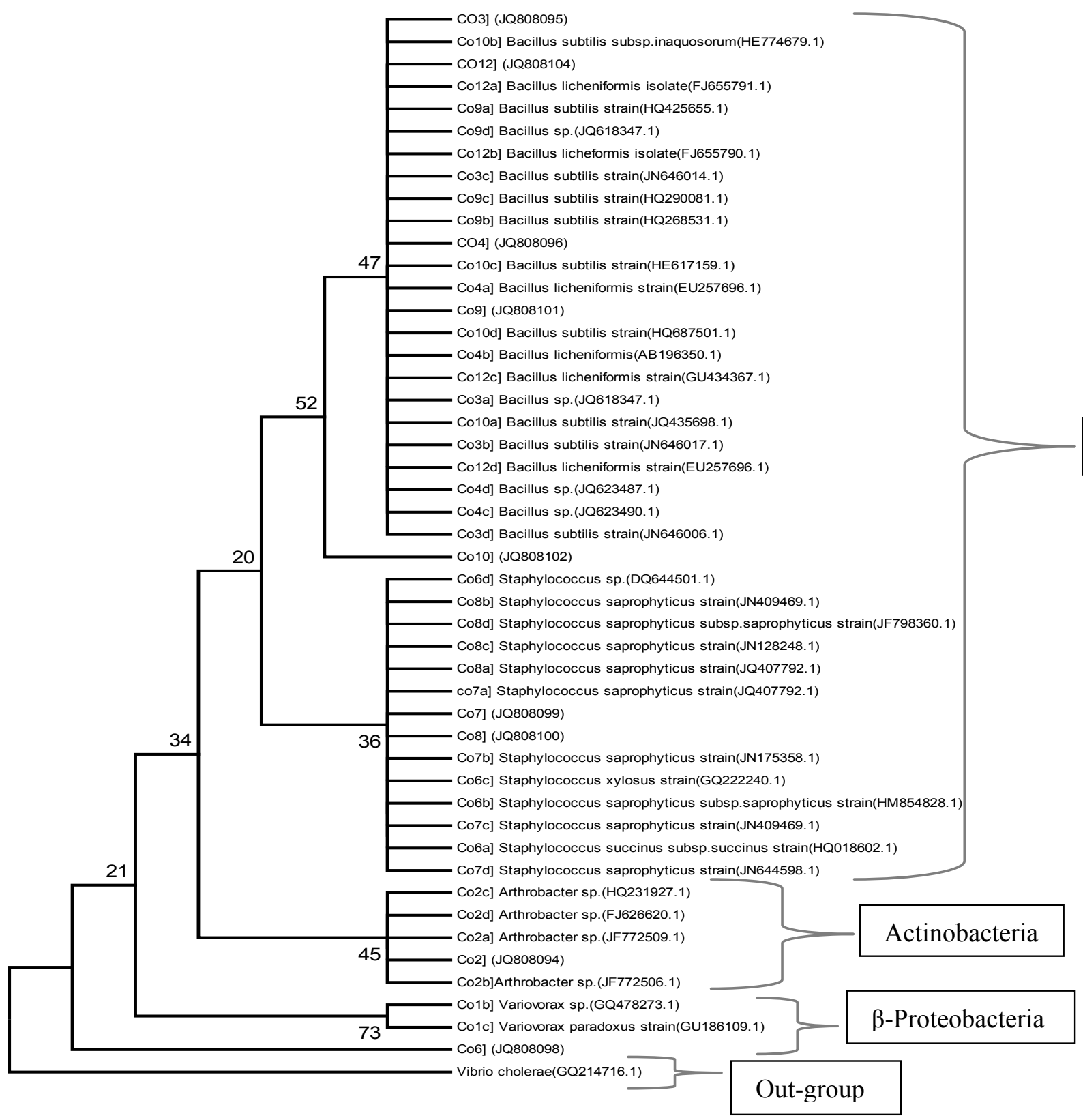

Firmicutes

Fig. 3. Neighbour joining tree showing partial sequences of $16 \mathrm{~S}$ rDNA of bacteria isolates from group 2 (cow) and their related species obtained from the GenBank as computed by boostrap NJ method 


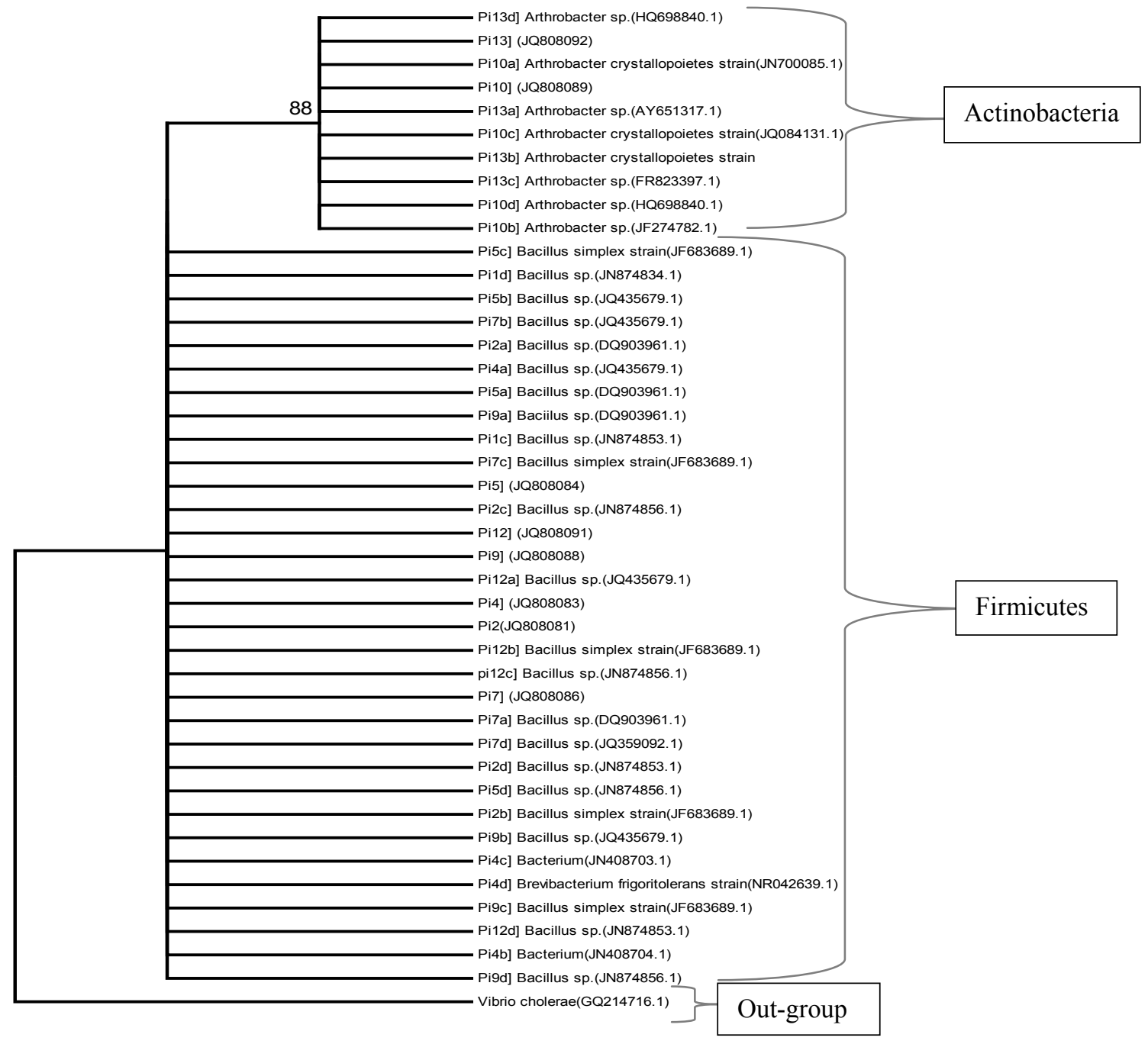

Fig. 4. Neighbour joining tree showing partial sequences of $16 S$ rDNA of bacteria isolates from group 4 (pig) and their related species obtained from the GenBank as computed by boostrap NJ method

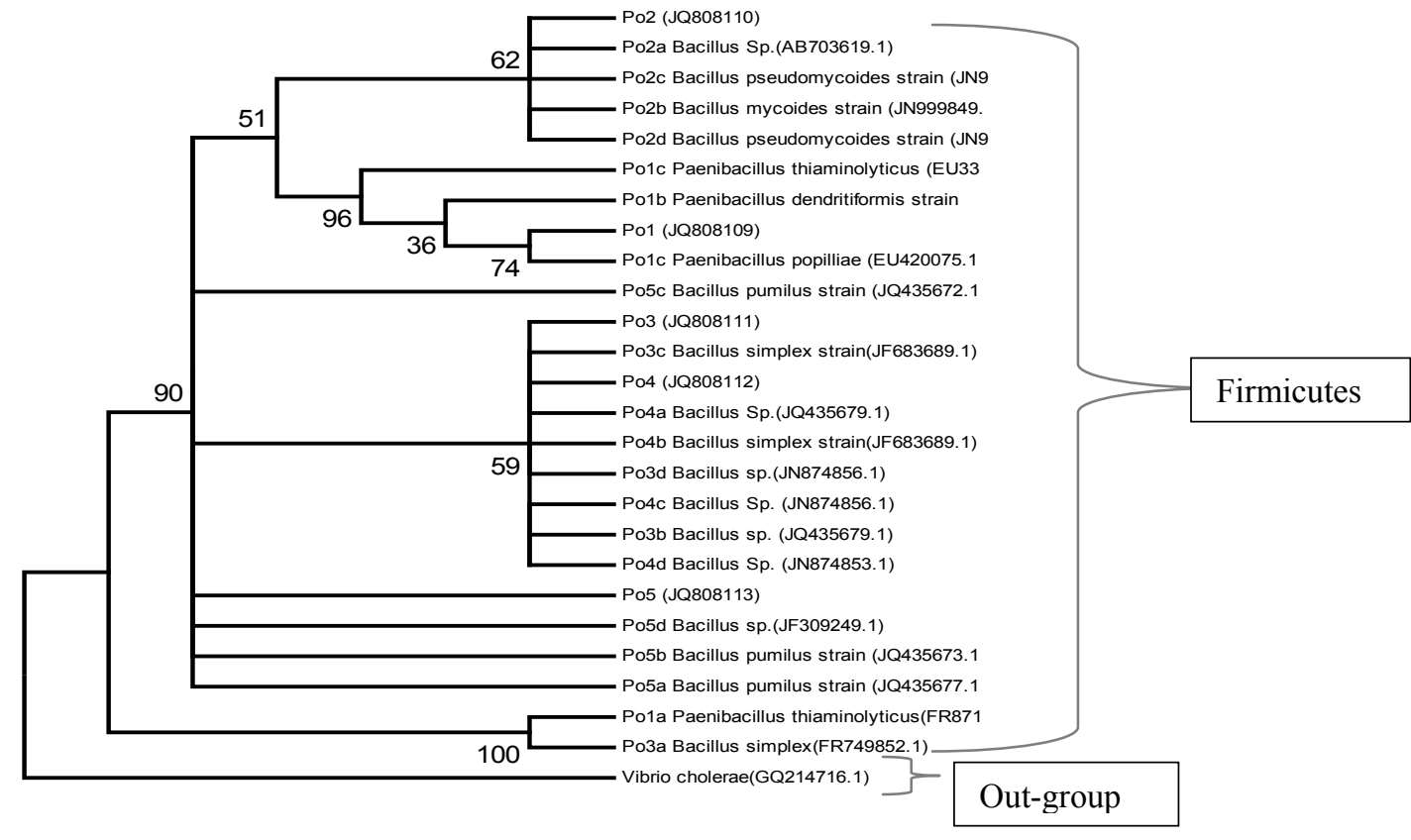

Fig. 5. Neighbour joining tree showing partial sequences of $16 \mathrm{~S}$ rDNA of bacteria isolates from group 5 (poultry) and their related species obtained from the GenBank as computed by boostrap NJ method 
Table 3. Reduction in concentrations of selected PAHs in enrichment culture. Values are mean of three actual values \pm standard error

\begin{tabular}{|c|c|c|c|c|c|}
\hline Selected PAH & $\begin{array}{l}\text { Initial conc. } \\
\left(\mathrm{mgkg}^{-1}\right)\end{array}$ & $\begin{array}{c}\text { Final conc. } \\
\text { Enrichment culture } \\
\left(\mathrm{mgkg}^{-1}\right)\end{array}$ & $\%$ reduction & $\begin{array}{l}\text { Final conc. Subculture } \\
\qquad\left(\mathrm{mgkg}^{-1}\right)\end{array}$ & $\%$ reduction \\
\hline Naphthalene & $95.32 \pm 0.03$ & $19.06 \pm 0.1$ & 80.00 & $31.77 \pm 2.14$ & 66.67 \\
\hline $\begin{array}{c}\text { 1-methyl } \\
\text { naphthalene }\end{array}$ & $205.81 \pm 10.14$ & $41.16 \pm 1.2$ & 80.00 & $51.38 \pm 1.92$ & 75.04 \\
\hline $\begin{array}{l}\text { 2-methyl } \\
\text { naphthalene }\end{array}$ & $195.70 \pm 0.01$ & $39.14 \pm 0.99$ & 80.00 & $48.93 \pm 3.96$ & 74.99 \\
\hline Acenaphtylene & $5.05 \pm 0.1$ & $1.01 \pm 0.09$ & 80.00 & $1.68 \pm 0.76$ & 66.73 \\
\hline Acenaphthene & $7.94 \pm 0.96$ & $1.59 \pm 0.64$ & 79.98 & $2.65 \pm 1.67$ & 66.63 \\
\hline Fluorene & $23.11 \pm 0.96$ & $4.62 \pm .69$ & 80.01 & $5.78 \pm 1.81$ & 74.99 \\
\hline Anthracene & $40.44 \pm 0.69$ & $9.09 \pm 0.18$ & 77.52 & $13.48 \pm 2.53$ & 66.67 \\
\hline Phenanthrene & $1.44 \pm 0.49$ & $0.29 \pm 0.14$ & 79.86 & $0.48 \pm 0.16$ & 66.67 \\
\hline Fluoranthene & $1.44 \pm 0.46$ & $0.36 \pm 0.13$ & 75.00 & $0.38 \pm 0.21$ & 73.61 \\
\hline Pyrene & $10.83 \pm 1.33$ & $2.71 \pm 1.06$ & 74.98 & $3.61 \pm 1.4$ & 66.67 \\
\hline Chrysene & $44.77 \pm 4.07$ & $8.95 \pm 1.7$ & 80.00 & $11.19 \pm 2.26$ & 75.01 \\
\hline $\begin{array}{l}\text { Benzo[a] } \\
\text { anthracene }\end{array}$ & $1.44 \pm 0.59$ & $0.26 \pm 0.13$ & 81.94 & $0.55 \pm 0.21$ & 61.81 \\
\hline $\begin{array}{c}\text { Benzo[b] } \\
\text { fluoranthene }\end{array}$ & $21.66 \pm 2.1$ & $4.33 \pm 1.28$ & 80.00 & $7.20 \pm 1.94$ & 66.67 \\
\hline $\begin{array}{c}\text { Benzo[k] } \\
\text { fluoranthene }\end{array}$ & $2.17 \pm 0.6$ & $0.43 \pm 0.14$ & 80.18 & $0.72 \pm 0.29$ & 66.82 \\
\hline $\begin{array}{l}\text { Benzo[a] } \\
\text { pyrene }\end{array}$ & $7.22 \pm 1.12$ & $1.44 \pm 0.46$ & 80.06 & $1.81 \pm 0.9$ & 74.93 \\
\hline $\begin{array}{l}\text { Indenol }(1,2,3- \\
\text { cd)pyrene }\end{array}$ & $5.78 \pm 1.38$ & $1.16 \pm 0.23$ & 79.93 & $1.45 \pm 0.58$ & 74.91 \\
\hline
\end{tabular}

using GC/MS which showed that these bacteria were able to utilise the hydrocarbons in 21 days (Table 3), as such it was indicated by the reduction in concentrations of the PAHs from initial to $61.81 \%$ or $80 \%$ respectively. This result is similar to those reported for the comparison of bioaugmentation and composting for remediation of oil sludge by Ouyang et al. (2005), suggesting the existence of active bacterial community in the culture media capable of utilizing oil sludge hydrocarbons (Katsivela et al. 2003). This implies that the animal manures were rich in nutrients necessary for basic microbial activities such as nitrogen, carbon and phosphorus, which were in substantial amounts and are necessary to stimulate microbial growth and activities in the compost piles.

The dominant bacteria species in all the treatment piles were the Bacillus species. The abundance of Bacillus spp. in all compost piles with manure, including the control, shows that they are indigenous to the soil. Bacillus and other bacteria identified in this study have been reported in different studies to be present in soils contaminated with petroleum hydrocarbons and have also been shown to degrade oil (Kumar et al. 2011). These organisms are also known to be involved in the utilization of hydrocarbons in soil as their sole source of carbon and energy (Kumar et al. 2011, Al-Wasify and Hamed 2014).

Some of the bacterial strains identified in this study are those that are efficient biosurfactant producers on petroleum hydrocarbon impacted soil. The biosurfactants they produce are capable of emulsifying oil sludge thus increasing the surface area of the substrates and enhancing solubility, allowing the constituent hydrocarbons to become available for bacteria biodegradation (Kumari et al. 2012). Biosurfactant production by bacteria has the advantage of being natural, non-toxic, biodegradable and a cost effective approach in solubilisation of oil sludge during biodegradation (Kumari et al. 2012). These biosurfactants secreted by bacteria are more effective than chemical surfactants in enhancing the solubility and biodegradation of petroleum hydrocarbons (Kumari et al. 2012). Other factors that may be responsible for the uptake and high metabolism of PAHs by these bacteria include growth condition of bacteria, for example, $\mathrm{pH}$ and temperature, presence of a specific and high amount of inducible enzymes secreted by the bacteria consortium, substrate specificity of PAHs degrading enzyme and bacteria cell surface hydrophobicity (Kumari et al. 2012). 
The results in Table 3 showed that at $28^{\circ} \mathrm{C}$, microbial consortia were able to utilise and break down the hydrocarbons because of increased solubility of the target contaminants. The principal mechanism for the aerobic bacterial co-metabolism of PAHs is the initial oxidation of the benzene ring by the action of dioxygenase enzymes to form cis-dihydrodiol, which are dehydrogenated to form dihydroxylated intermediates that can be metabolised further via catechols to $\mathrm{CO}_{2}$ and $\mathrm{H}_{2} \mathrm{O}$. Cis-dihydrodiols of PAHs are potentially soluble and more bioavailable (Barmforth and Singleton 2005). Reports have shown that most bacteria species have individual capabilities to degrade hydrocarbons (PAHs) completely or carry out their transformation and mineralisation to different extents (Liu et al. 2010, Kumar et al. 2011, Wang et al. 2011, Barnabas et al. 2013, Al-Wasify and Hamed 2014, Singh and Chandra 2014, Vanishree et al. 2014). However, the objective of this present study is to determine the degradative action of microbial consortia with broad capabilities to degrade complex crude oil sludge not the action of individual organisms in each compost piles.

Bacillus species have been reported to have the potentials to degrade and transform different PAHs but may not mineralise them while Mycobacterium sp. has the potentials of degradation, transformation and mineralisation for most PAHs, using dioxygenases attack (Sho et al. 2004). However, Mycobacterium spp. is very selective in the initial oxidation of PAHs (Moody et al. 2004). Bacillus sp. have been isolated and identified from soil contaminated with oil refinery wastewaters, which have the potential to biodegrade and utilise organic compounds such as PAHs of both low and high molecular weight as sole source of carbon (Gupta, 2012). Bacillus subtilis, which is one the dominant bacteria species identified in this study have been reported to have the potentials to utilise several PAHs including benzo(a)pyrene, anthracene, naphthalene and dibenzothiophene as sole source of carbon energy (Lily et al. 2009, Gupta 2012).

It was also stated that staphylococcus strain, another bacterial species identified in this study can biotransform PAHs such as phenanthrene using the mono and di -oxygenases by initial attack at $\mathrm{C} 1$ and $\mathrm{C} 2$ position giving 1, 2, dihydroxy phenanthrene to catechol (Mallick et al.2007). Arthrobacter species have been isolated from soil contaminated with heavy metals and aromatic hydrocarbons. They are extremely tolerant and resistant to most metals and other toxic substances, but able to degrade some hydrocarbons to its less toxic form (Unell, 2008). Arthrobacter species in conjunction with several other strains use their vast co-metabolic activities to degrade pollutants in a synergistic relationship, using their target contaminant as their sole source of carbon and energy. Cameotra and Makkar (2010) reported that Arthrobacter sp., which were also identified in this study have specific adhesion mechanisms and produce extracellular emulsifying agents for contact with water-insoluble hydrocarbons. Hence, their presence in pig and cow compost treatment of this present study (Figs 2 and 4), suggesting that they may be useful in bioremediation (Unell 2008). Paenibacillus species also have been isolated from a wide variety of sources and petroleum contaminated sediments, they can withstand environmentally stressful conditions which allow them long term survival (Ganesh and Lin, 2009), hence their presence in poultry and control compost treatment of this present study (Figs 1 and 5). Paenibacillus species are capable of fixing nitrogen, phosphate solubilisation and degradation of environmental pollution (Sirota-Madi et al. 2010). They can also produce extracellular enzymes such as polysaccharides-degrading enzymes and protease which can catalyse a wide variety of synthetic reactions and utilise aromatic substrates (PAH-degradation) in the field (Sirota-Madi et al. 2010), suggesting their presence in this present study. Variovorax species identified in this study have been isolated from agricultural soils and found to degrade a broad range of different compounds such as pesticides and herbicides intermediates to $\mathrm{CO}_{2}$ (Sørensen et al. 2008). Sørensen et al. (2008) used a combination of Variovorax sp. Strain SRS16 and Arthrobacter globiformis strain D47 to mineralise phenylurea herbicide diuron and its intermediates by hydrolysis of amide bond to $\mathrm{CO}_{2}$. These organisms have close relationship based on their similarity in their degradation pathways, hence their presence and phylogenetic relationship in Fig. 2 of this present study. In this study, Mycobacterium was not identified possibly because the organism is typically abundant in river and water sediments (Churchill et al. 1999), unlike Bacillus, Arthrobacter and Variovorax that are soil borne organism, which were dominant in this study (Kumar et al. 2011, Al-Wasify and Hamed 2014).

The bacterial population that was isolated from the liquid enrichment cultures were those bacteria adapted to growing on and utilising hydrocarbon compounds as sole source of carbon (Yousefi Kebria et al. 2009, Harikrishna Yadav et al. 2012). The oil amended medium was a growth control medium meant to exclude heterotrphic bacteria leaving the active bacterial community responsible for oil sludge degradation during compost bioremediation of oil sludge. The results obtained in this study indicated that Bacillus species were predominant in this study and as such they may have higher potential and are major contributors among other isolated bacterial strains to degrade oil. Strains of Bacillus species have potential to grow on a large number of hydrocarbon compounds as a source of carbon and energy demonstrating that they might be efficient hydrocarbon degraders (Kumar et al. 2011, Al-Wasify and Hamed 2014). Bacillus species are more tolerant to high levels of oils due to their resistant endospores. They are known to possess a more competent and active oil degrading enzymes than other biodegraders (Darsa et al. 2014). Degradation of oil by these microbial consortia shows that they have specialized cometabolic capacities. In oil polluted environments, specialised bacterial consortiums are abundant because of their adaptation ability to pollutants. It has also been shown that these bacteria are the most predominant microorganism among others in either in situ or ex situ bioremediation processes, indicating that they are the main agents responsible for the degradation of oil. The results obtained in this study have shown that the wide variety of bacterial consortiums identified is possibly responsible for the degradation of the oil sludge components in all compost piles. The use of these native bacterial consortiums with oil utilising capabilities as seed onto oil-contaminated environment could prove a more environmentally-friendly approach to bioremediation.

\section{Acknowledgement}

The authors wish to acknowledge the financial support given by the South African National Research Foundation for this project. 


\section{References}

Al-Wasify, R.S. \& Hamed, S.R. (2014). Bacterial biodegradation of crude oil using local isolates, Internationl Journal of Bacteriology, 2014, pp. 1-8.

Barmforth, S.M \& Singleton, I. (2005). Bioremediation of PAHs: Current knowledge and future direction, Journal of Chemical Technology and Biotechnology, 80, pp. 723-736.

Barnabas, J., Saha, S., Singh, V. \& Das, S. (2013). Effect of enzymes extracts on bacterial degradation of garage petroleum oils, Journal of Environmental Science, Computer Science and Engineering \& Technology, 2, 2, pp. 206-211.

Bayoumi, R.A. (2009). Bacterial bioremediation of polycyclic aromatic hydrocarbons in heavy oil contaminated soil, Journal of Applied Sciences Research, 5, 2, pp.197-211.

Bobak, D.M. (2010). Polycyclic aromatic hydrocarbon characterization in Otter Creek, Northwest Ohio. Submitted as partial fulfilment of the requirements for the Master of Science Degree in Geology, College of Graduate Studies, University of Toledo 2010.

Bojes, H.K. \& Pope, P.G. (2007). Characterization of EPA's 16 priority pollutant polycyclic aromatic hydrocarbons (PAHs) in tank bottom solids and associated contaminated soils at oil exploration and production sites in Texas, Regulatory Toxicology and Pharmacology, 47, 3, pp. 288-295.

Cameotra, S.S. \& Makkar, R.S. (2010). Biosurfactant-enhanced bioremediation of hydrophobic pollutants, Pure and Applied Chemistry, 82, pp. 97-116.

Churchill, S.A., Harper, J.P. \& Churchill, P.F. (1999). Isolation and characterization of a Mycobacterium species capable of degrading three- and four-ring aromatic and aliphatic hydrocarbons, Applied and Environmental Microbiology, 65, 2, pp. 549-552

Darsa, K.V., Thatheyus, J.A. \& Ramya, D. (2014). Biodegradation of Petroleum compound using the bacterium Bacillus subtilis, Science International, 2, 1, pp. 20-25.

Diallo, M., Cagin, T., Faulon, J.L. \& Goddard, W.A. (2000). Thermodynamic properties of asphaltene: a predictive approach based on computer assisted structure elucidated and atomistic simulations, in: Asphaltene and asphalts II, Yen, T.F. \& Chilingarian, G.V. (Eds.). Developments in petroleum science 40B, Elsevier Amsterdam, pp.103-127.

Ganesh, A. \& Lin, J. (2009). Diesel degradation and biosurfactant production by Gram-positive isolates, African Journal of Biotechnology, 8, 21, pp. 5847-5854.

Gupta, B. (2012). Isolation and characterisation of Naphthalene degrading bacteria. A Master's thesis submitted to the department of Environmental Science and Technology, Tharpar University, Patiala 2012

Harikrishna, Y.N., Narasimhulu, K. \& Bhanu, P.M. (2012). Studies on the potential of bacillus subtilis in the biodegradation of engine oil, Journal of Chemical, Biological and Physical Sciences, 2, 3, pp. 1599-1603.

Inceoglu, O., Hoogwout, E.F., Hill, P. \& van Elsas, J.D. (2010). Effect of DNA extraction method on the apparent microbial diversity of soil, Applied and Environmental Microbiology, 76, pp. $3378-3382$.

Katsivela, E., Moore, E.R.B. \& Kalogerakis, N. (2005). Biodegradation of aliphatic and aromatic hydrocarbons: specificity among bacteria isolated from refinery waste sludge, Water, Air and Soil Pollution: Focus, 3, pp. 103-115.

Kumar, A., Munjal, A. \& Sawhney, R. (2011). Crude oil PAH constitution, degradation pathway and associated bioremediation microflora: An overview, Journal of Environmental Science, 1, 7, pp. 1420-1439.

Kumari, B., Singh, S.N. \& Singh, D.P. (2012). Characterization of two biosurfactant producing strains in crude oil degradation, Process Biochemistry, 47, pp. 2463-2471.
Lily, M.K., Bahuguna, A., Dangwal, K. \& Garg, V. (2009). Degradation of benzo(a)pyrene by a novel strain bacillus subtilis BMT4i (MTCC 9447), Brazilian Journal of Microbiology, 40, pp. 884-892.

Liu, W., Luo, Y., Teng, Y., Li, Z. \& Ma, L.Q. (2010). Bioremediation of oily sludge-contaminated soil by stimulating indigenous microbes, Environmental Geochemistry and Health, 32, pp. 23-29.

Machin-Ramirez, C.A.I., Okoh, D.K., Morales, M., Mayolo-Deloisa, R. \& Trejo-Hernaindez, Q. (2008). Slurry-phase biodegradation of weathered oily sludge waste, Chemosphere, 70, pp. 737-744.

Mallick, S., Chatterjee, S. \& Dutta, T.K. (2007). A novel degradation pathway in the assimilation of phenanthrene by Staphylococcus sp. strain $\mathrm{PN} / \mathrm{Y}$ via meta-cleavage of 2-hydroxy-1-naphthoic acid: formation of trans-2,3-dioxo-5-(29-hydroxyphenyl)-pent4-enoic acid, Microbiology, 153, pp. 2104-2115.

Marin Millản, J.A. (2004). Bioremediaciỏn, mediante tẻcnicas biolỏgicas, de hidrocarburos contenidos en lodos de refinerỉa. Experinecias en clima semiảrido, PhD thesis, Murcia University 2004.

Mokni-Tlili, S., Jaoua, L., Murano, F., Jedidi, N. \& Hassen, A. (2009). Study of the effects of urban organic residues on the distribution of culturable actinomycetes in a Tunisian agricultural soil, Waste Management \& Research, 27, pp. 224-232.

Moody, J.D., Fu, P.P., Freeman, J.P \& Cerniglia, C.E. (2004). Regioand stereoselective metabolism of 7,12-Dimethylbenz $[a]$ anthracene by Mycobacterium vanbaalenii PYR-1, Applied and Environmental Microbiology, 69,7, pp. 3924-3931

Ouyang, W., Liu, H., Murygina, V., Yu, Y., Xiu, Z. \& Kalyuzhny, S. (2005). Comparison of bioaugmention and composting for remediation of oil sludge. A field-scale study in China, Process Biochemistry, 40, pp. 3763-3768.

Paulauskiene, T., Zabukas, V. \& Vaitiekunas, P. (2009). Investigation of volatile organic compound (VOC) emission in oil terminal storage Tank Park, Journal of Environmental Engineering and Landscape Management, 17, 2, pp. 81-89.

Phillips, T.M., Liu, D., Seech, A.G., Lee, H. \& Trevors, J.T. (2000). Monitoring bioremediation in creosote-contaminated soils using chemical analysis and toxicology tests, Journal of Industrial Microbiology and Biotechnology, 65, pp. 627.

Saman, S., Slattery, P. \& Saman, S. (2010). Microbial Biodiversity Investigation techniques. Life Sciences Department, Massachusetts Bay Community College, Wellesley, MA. 02481, USA, Applied Microbiology and Biotechnology, pp.1546-1550.

Sonawdekar, S. (2012). Bioremediation: A boon to hydrocarbon degradation, International Journal of Environmental Sciences, 2, 4, pp. 2408-242.

Sho, M., Hamel, C. \& Greer, C.W. (2004). Two distinct gene clusters encode pyrene degradation in Mycobacterium sp. strain S65, FEMS Microbiology Ecology, 48, pp. 209-220.

Singh, K. \& Chandra, S. (2014). Treatment of petroleum hydrocarbon polluted environment through bioremediation: A review, Pakistan Journal of Biological Sciences, 17, 1, pp. 1-8.

Sirota-Madi, A., Olender, T., Helman, Y., Ingham, C., Brainis, I., Roth, D., Hagi, E., Brodsky, L., Leshkowitz, D. \& Galatenko, V. (2010). Genome sequence of the pattern forming Paenibacillus vortex bacterium reveals potential for thriving in complex environments, BMC Genomics, 11, pp. 710.

Sørensen, S.R., Albers, C.N. \& Aamand, J. (2008). Rapid mineralisation of the phenylurea herbicide diuron by Variovorax sp. Strain SRS16 in pure culture and within a two-member consortium, Applied and Environmental Microbiology, 74, 8, pp. 2332-2340.

Srinivasarao-Naik, B., Mishra, I.M. \& Bhattacharya, S.D. (2011). Biodegradation of total petroleum hydrocarbons from oily sludge, Bioremediation Journal, 15, 3, pp. 140-147.

Udotong, I.R., Udotong, I.J., Inam, E. \& Kim, K. (2011). Bioconversion of crude oil production into soil conditioner Using sawdust as Organic amendment, Geosystem Engineering, 14, 2, pp. 51-58. US EPA method 3541(SW-846) (1994). Automated Soxhlet Extraction. 
Unell, M. (2008). Physiological, genetic and proteomic characterisation of Arthrobacter Chlorophenolicus during growth on different phenolic substrates or temperature. A PhD. Thesis submitted to the Department of Microbiology, Faculty of Natural Resource and Agricultural Science, Swedish University of Agricultural Science, Uppsala 2008.

US EPA method 8270 (2007). Semivolatile organic compounds by gas chromatography/ mass spectrometry (GC/MS).

Vanishree, M., Thatheyus, A.J. \& Ramya, D. (2014). Biodegradation of petrol using Aspergillus sp, Annual Review \& Research in Biology, 4, 6, pp. 914-923.
Wang, Q., Zhang, S., Li, Y. \& Klassen, W. (2011). Potential approaches to improving biodegradation of hydrocarbons for bioremediation of crude oil pollution, Journal Environmental Protection, 2, pp. $47-55$

Kebria, D.Y., Khodadadi, A., Ganjidoust, H., Badkoubi, A. \& Amoozegar, M.A. (2009). Isolation and characterization of a novel native Bacillus strain capable of degrading diesel fuel, International journal of Environmental Science and Technology, 6, 3, pp. 435-442. 